\title{
Water reuse for irrigated agriculture in Jordan: challenges of soil sustainability and the role of management strategies
}

Article

Accepted Version

Carr, G., Nortcliff, S. and Potter, R. B. (2010) Water reuse for irrigated agriculture in Jordan: challenges of soil sustainability and the role of management strategies. Philosophical

Transactions of the Royal Society A: Mathematical, Physical and Engineering Sciences, 368 (1931). pp. 5315-5321. ISSN 1364-503X doi: https://doi.org/10.1098/rsta.2010.0181

Available at https://centaur.reading.ac.uk/8155/

It is advisable to refer to the publisher's version if you intend to cite from the work. See Guidance on citing.

To link to this article DOI: http://dx.doi.org/10.1098/rsta.2010.0181

Publisher: Royal Society Publishing

All outputs in CentAUR are protected by Intellectual Property Rights law, including copyright law. Copyright and IPR is retained by the creators or other copyright holders. Terms and conditions for use of this material are defined in the End User Agreement. 


\section{CentAUR}

Central Archive at the University of Reading

Reading's research outputs online 


\section{PHILOSOPHICAL THE ROYAL A MATHEMATICAL, TRANSACTIONS THYSICAL OF- SOCIETY $\triangle 1$ SCIEnCES}

Water reuse for irrigated agriculture in Jordan: challenges of soil sustainability and the role of management strategies

\begin{tabular}{|r|l|}
\hline Journal: & Philosophical Transactions A \\
\hline Manuscript ID: & RSTA-2010-0181 \\
\hline Article Type: & Research \\
\hline $\begin{array}{r}\text { Date Submitted by the } \\
\text { Author: }\end{array}$ & $14-$ May-2010 \\
\hline Complete List of Authors: & $\begin{array}{l}\text { Carr, Gemma; Vienna University of Technology, Centre for Water } \\
\text { Resource Systems } \\
\text { Nortcliff, Stephen; University of Reading, Department of Soil } \\
\text { Science } \\
\text { Potter, Rob; University of Reading, Department of Geography }\end{array}$ \\
\hline Subject: & Hydrology < EARTH SCIENCES, Pedology < EARTH SCIENCES \\
\hline Select Issue Title: & Water and Society \\
\hline Keywords: & $\begin{array}{l}\text { perceptions, reclaimed water, soil management, salinity, } \\
\text { Wastewater }\end{array}$ \\
\hline &
\end{tabular}

\section{ScholarONE \\ Manuscript Central}




\title{
Water reuse for irrigated agriculture in Jordan: challenges of soil sustainability and the role of management strategies
}

\author{
G. Carr ${ }^{1}$, S. Nortcliff ${ }^{2}$ and R.B. Potter ${ }^{3}$ \\ ${ }^{1}$ Corresponding author, Centre for Water Resource Systems, Vienna University of Technology, Karlsplatz \\ 13/222 (E-mail: carr@waterresources.at) \\ ${ }^{2}$ Department of Soil Science, School of Human and Environmental Sciences, University of Reading, UK \\ ${ }^{3}$ Department of Geography, School of Human and Environmental Sciences, University of Reading, UK
}

\begin{abstract}
Reclaimed water provides an important contribution to the water balance in water scarce Jordan but the quality of this water presents both benefits and challenges. Careful management of reclaimed water is required to maximise the nutrient benefits while minimising the salinity risks. This work utilises a multi-disciplinary research approach to show that soil response to irrigation with reclaimed water is a function of the management strategies adopted on the farm by the water user. The adoption of management methods to maintain soil productivity can be seen to be a result of farmers' awareness to potentially plant toxic ions in the irrigation water (70 per cent of Jordan Valley farmers identified salinisation as a hazard from irrigation with reclaimed water). However, the work also suggests that farmers' management capacity is affected by the institutional management of water. Thirty-five per cent of farmers in the Jordan Valley claimed their ability to manage salinisation was limited by water shortages. Organisational interviews revealed that institutional awareness of soil management challenges was quite high (34 per cent of interviewees described salinisation as a risk from water reuse), but strategies to address this challenge at the institutional level require greater development.
\end{abstract}

Keywords: perceptions; reclaimed water; soil management; salinity; wastewater

\section{Introduction}

Jordan is a country with very limited water resources and treated domestic wastewater offers a valuable contribution to the country's water balance. Water reuse is particularly well-suited to irrigated agriculture, for which water is in constant demand. Approximately 51 per cent of all domestic wastewater originating from households in urban areas was collected and treated in 2002 and almost all of the treated effluent (reclaimed water) is used for irrigated agriculture (Ministry of Water and Irrigation, 2004). The quantity of wastewater being collected, treated and made available for irrigation is also rising due to increasing urbanisation (Darmame and Potter 2009, 2010; Potter and Darmame, 2010; Potter et al., 2009) resulting in a greater percentage of the country's population being connected to the sewerage network.

The use of reclaimed water for irrigation presents a number of benefits and challenges due to the nature of the water quality. Reclaimed water in arid countries is typically slightly saline and can also have a relatively high concentration of boron (Feign et al., 1991). These ions are potentially plant toxic and crop productivity and the long-term sustainability of the soil can be jeopardised if suitable management of the soil and water is not employed. Despite this challenge, reclaimed water can also contain significant quantities of plant beneficial ions (nutrients) such as nitrogen, phosphorous and potassium. Careful management of the water is therefore required to prevent detrimental effects on soil and crops while benefitting from the "free" nutrients in the water that can enhance yields without the additional costs of chemical fertilisers (Lazarova et al., 2005; Qadir et al., 2010). 
Our research into water reuse in Jordan aimed to explore how irrigation with reclaimed water affects soil sustainability with particular consideration for the role of water management decisions taken both on and off the farm. Several research aims were identified:

1) How does water reuse affect soil sustainability?

2) How do farmers using reclaimed water perceive the resource and how do they recognise and manage the benefits and limitations?

3) How do the institutions involved in managing reclaimed water view the resource and how do they recognise their role in maintaining soil sustainability?

A multidisciplinary research approach involving both the natural and social sciences was therefore taken in order to explore how aspects of soil sustainability were affected by irrigation with reclaimed water and how the management of the water on the farm and away from the farm affected the soil. This approach was selected with the intention of gaining a wide and holistic view of the numerous processes taking place that result in soil changes due to irrigation with reclaimed water. It was expected that soil response would be a function not just of water quality, but also of water management at multiple scales (from the farmer's field to the government's catchment management plan). As such, simultaneous investigation of soil and water management at the farm and institutional level was deemed to be essential in this research.

\section{Research methods}

A range of research methods was therefore used which included reclaimed water sampling and standard chemical analysis (including $\mathrm{pH}$ measurement, electrical conductivity measurement and concentrations of major cations and anions determined with inductively coupled plasma optical emission spectroscopy and ion chromatography respectively). Soils which had been irrigated with reclaimed water for known periods of time were sampled and analysed to determine the chemical character of the soil saturation extract, which is commonly used to represent the soil solution (Bressler et al., 1982). The standard method given by Rowell (1995) was followed. Water and soils were sampled from the irrigated area surrounding Khirbet As Samra wastewater treatment plant (located in the arid eastern desert of Jordan), Ramtha wastewater treatment plant (located in the semi-arid northern highlands of Jordan) and Deir Alla (located in the central Jordan Valley, where a mixture of freshwater and reclaimed water from the King Talal Reservoir is used for irrigation) (see Carr, 2009 for further details).

Following well-established methodological approaches (Kitchen and Tate, 2000; Desai and Potter, 2006), semi-structured interviews were conducted with a total of 39 farmers irrigating with reclaimed water to document and investigate their experiences and perceptions and the strategies they employ in seeking to manage soil risks from reclaimed water on the farm. These were mainly conducted with the assistance of a translator with advanced knowledge of agricultural systems in Jordan. The role of international agencies, governmental, non-governmental, private and research organisations in water reuse was also considered through semi-structured interviews with a total of 29 organisational representatives. These interviews paid particular attention to the effects of water resource decision-making on water quality and water quantity provision to the farm, and the effect of these actions for the soil management 
strategies adopted by the farmer. Interviews were either recorded or notes were taken and these were typed up or transcripts prepared immediately after the interviews. Following the guidelines of Kitchin and Tate (2000), each "data bit" (piece of information) within the transcripts was then coded following a coding framework developed for each of the interview groups (farmers and organisations). Through examining each similarly coded group of data bits, similarities and differences became clear and narratives could be developed around specific themes.

\section{Results and Discussion}

Water sampling and analysis, combined with data available in the literature, revealed that the reclaimed water from the selected study sites in Jordan contained significant quantities of both plant beneficial ions and potentially plant toxic ions (Table 1). The phosphate in the reclaimed water is of particular benefit as it has the potential to meet a substantial proportion of crop requirements at Khirbet As Samra and in the Jordan Valley, depending on the crops grown and the intensity of cropping. At Ramtha, the concentration of phosphate is lower due to the removal of this nutrient during wastewater treatment. The removal of phosphate during treatment is perhaps questionable due to the use of the water for irrigation directly around the wastewater treatment plant and the value of the phosphate for crop productivity (Carr, 2010).

The chloride, sodium and boron in the irrigation water have the potential to reach concentrations in the soil beyond which a reduction in crop productivity can be experienced, based on guidance by the Food and Agriculture Organisation (Ayers and Westcott, 1985). The effect of solute accumulation is highly dependent on the sensitivity of the crop to these ions (Maas, 1987). Additionally, a high proportion of sodium relative to other positively charged ions in the soil can cause soil structural problems (Oster and Jayawardane, 1998). The sodium adsorption ratio (SAR) is an indicator of the sodium risk and the data suggest that the water at Khirbet As Samra may present a soil sodicity risk, but this would be dependent on the physical properties of the soil and its response to elevated sodium (Rowell, 1994).

Table 1 Selected water quality parameters for reclaimed water from Khirbet As Samra, Ramtha and the King Talal Reservoir based on samples collected in the field and available published data (GTZ, 2005; Al-Zu'bi, 2007; Ammary, 2007; Bashabsheh, 2007)

(near here)

Analysis of soils irrigated with reclaimed water for extended periods of time showed that the management methods employed by the farmers altered the accumulation of potentially plant toxic ions in the soil. Figure 1 shows how soil in the Jordan Valley which has been irrigated with reclaimed water for 28 years has a low solute concentration (electrical conductivity in the soil saturation extract) in the crop root zone. This reflects the regular application of leaching water by the farmer in order to transfer solutes through the soil profile. In comparison, the electrical conductivity of the soil irrigated for 18 years at Khirbet As Samra, shown in Figure 1, is much higher throughout the soil profile and reflects how leaching has not taken place on this soil. Leaching has not been conducted because the land has been used for olive cultivation, olives having a deeper rooting depth and so not being sensitive to salinity in the upper soil profile. 
Figure 1. Soil salinity (measured by the electrical conductivity of the soil saturation extract) in soils irrigated with reclaimed water for extensive periods of time (error bars show standard error from the mean)

(near here)

Interviews with farmers showed a high awareness to salinity risk in the Jordan Valley and 70 per cent of farmers identified soil salinisation as a hazard due to irrigation with reclaimed water. In contrast, farmers using reclaimed water directly around the wastewater treatment plants of Ramtha and Khirbet As Samra were not so concerned about salinity (18 per cent). This is likely to be due to the use of flood irrigation directly around the treatment plants which results in the regular flushing of the solutes through the soil. Flood irrigation is possible around the treatment plants due to high water availability and the use of irrigation as a form of waste disposal. Drip irrigation is used in the Jordan Valley as a result of low availability of water, resulting from the high intensity of cropping, both seasonally and spatially (Molle et al, 2008).

The interviews with farmers in the Jordan Valley revealed that although awareness of salinity risk was high, and the need for leaching was recognised, 35 per cent of the farmers interviewed described how their capacity to leach was limited due to water shortage. Farmers acknowledged that this was a result of the environmental conditions of low rainfall and high evaporation in Jordan, but it was also noted by several farmers that institutional weaknesses affected their ability to maintain the soil in a sustainable manner. Issues identified included: the distribution of water between farmers, with some farmers describing how they received very little water while their neighbour received plenty; the seasonal distribution of water, with resources being supplied in higher quantities than required in winter and not supplied in sufficient quantities at other times of the year; inadequate management of water infrastructure, such as canals; and the enforcement of regulations to protect the quality of the irrigation water (for example, though preventing industrial waste entering the domestic wastewater system).

Interviews with organisations showed that there was high awareness among this stakeholder group with regard to the protection of the soil resource (34 per cent of interviewees identified salinisation as a risk from water reuse). However, no organisations discussed their role in protecting soil sustainability through ensuring the water provided to farmers is of a suitable quality and quantity to meet their needs. Awareness of risks from reclaimed water quality was present, but this was primarily with regards to human health protection.

\section{Conclusions}

This work has shown that the use of reclaimed water for irrigation in Jordan does have the capacity to affect the soil in a detrimental manner, but the effect of the water on soils can be managed through the application of suitable strategies on the farm. Farmers recognise the challenges and the benefits of using reclaimed water for irrigation, and endeavour to manage the risks to minimise the detrimental effects on the soil and to maintain productivity. However, their capacity to manage their soil is intricately connected to the management of water at the institutional level through the control of water quality and the provision of water in quantities and at the times it is required by farmers. It is stressed that the multidisciplinary approach adopted has proved to be of immense value for this study due to its capacity to both document physical processes 
taking place in the soil, and to link these directly with processes of water management taking place at the farm- and institutional-levels.

\section{Acknowledgements}

This work formed part of the Water, Life and Civilisation Project at the University of Reading and was funded by the Leverhulme Trust. The authors would especially like to thank all the farmers and organisation representatives who generously gave their time for the interviews and the superb and dedicated translation assistance of a number of invaluable individuals.

\section{References}

Al-Zu'bi, Y. (2007) Effect of irrigation water on agricultural soil in Jordan Valley: An example from arid area conditions. Journal of Arid Environments. 70 pp. 63-79

Ammary, B.Y. (2007) Wastewater reuse in Jordan: Present status and future plans. Desalination 211 pp. 164-176

Ayers, R.S. and Westcott, D.W. (1985) Water Quality for Agriculture. Irrigation and Drainage Paper 29. Rev 1. Food and Agriculture Organisation of the United Nations, Rome, Italy

Bashabsheh, I.M. (2007) Impact of treated wastewater on soil properties and cut flower production under drip irrigation systems. Unpublished MSc Thesis. Jordan University of Science and Technology, Jordan

Bressler, E., McNeal, B.L. and Carter,D.L. (1982) Saline and Sodic Soils: PrinciplesDynamics-Modeling. Advanced Series in Agricultural Sciences 10. Springer-Verlag, Berlin, Germany

Carr, G. (2010) Water reuse for irrigated agriculture in Jordan: soil sustainability, perceptions and management. Chapter 24 In: Mithen, S. and Black, E. (eds) Water, Life and Civilisation. Cambridge University Press/UNESCO International Hydrology Series, UK

Carr, G. (2009) Water reuse for irrigated agriculture in Jordan: soil sustainability, perceptions and management. Unpublished PhD Thesis. Department of Soil Science and Department of Geography, University of Reading, UK

Darmame, K. and Potter, R.B. (2009) 'Gestion de la rarete de l'eau a Amman: rationnement de l'offre et practiques des usagers', Espaces et Societies, 139, in press

Darmame, K. and Potter, R.B. (2010) Political discourses and public narratives on water supply issues in Amman, Jordan. Chapter 28 in: Mithen, S. and Black, E. (eds) Water, Life and Civilisation. Cambridge University Press/UNESCO International Hydrology Series, UK

Desai, V and Potter R B (2006) Doing Development Research, Sage: London, Thousand Oaks and New Delhi 
Feign, A., Ravina, I. and Shalhevet, J. (1991) Irrigation with Treated Sewage Effluent. Springer-Verlag, Israel

GTZ (2005) Long-term groundwater and soil monitoring concept - Final Report 2005. Reclaimed Water Project of the Deutsche Gesellschaft für Technische Zusammenarbeit, Amman, Jordan

Kitchin, R. and Tate, N.J. (2000) Conducting Research in Human Geography: Theory, Methodology and Practice. Prentice Hall, UK

Lazarova, V., Bouwer, H. and Bahri, A. (2005) Water Quality Considerations. pp. 31-63 In: Lazarova, V. and Bahri, A (eds) Water reuse for irrigation: agriculture, landscapes and turf grass. CRC Press, Boca Raton, USA

Maas, E.V. (1987) Salt tolerance of plants. In: Christie, B.R. (ed.) The Handbook of Plant Science in Agriculture. CRC Press, Boca Raton, Florida, USA

Ministry of Water and Irrigation, Jordan. (2004) National Water Master Plan of Jordan, Amman, Jordan

Molle, F., Vernot, J.P. and Hassan, Y. (2008) Irrigation in the Jordan Valley: Are water pricing policies overly optimistic? Agricultural Water Management 95 pp. 427-438

Oster, J.D. and Jayawardane, N.S. (1998) Agricultural management of sodic soils. Chapter 8 in Sumner, M.E. and Naidu, R. (eds) Sodic Soils: Distribution, Properties, Management, and Environmental Consequences. Oxford University Press. New York, USA

Potter, R.B., Darmame, K., Barham, N. and Nortcliff, S. (2008) "Ever-growing Amman", Jordan: urban expansion, social polarisation and contemporary urban planning issues. Habitat International 33(1) pp. 81-92

Potter, R.B. and Darmame, K (2010) 'Contemporary social variations in household water use, management strategies and awareness under conditions of water stress: the case of Greater Amman, Jordan', Habitat International, 15, 115-124

Qadir, M., Wichelns, D., Rashid-Sally, L., McCornick, P.G., Drechsel, P., Bahri, A. and Minhas, P.S. (2010) The challenges of wastewater irrigation in developing countries. Agricultural Water Management 97 (4) pp. 561-568

Rowell, D.L. (1994) Soil Science. Methods and Applications. Pearson Education. UK 


\begin{tabular}{|c|c|c|c|c|c|c|c|c|c|c|c|}
\hline \multirow[t]{2}{*}{ Location } & \multicolumn{5}{|c|}{$\begin{array}{l}\text { Potentially plant beneficial ions in the irrigation } \\
\text { water }\left(\mathrm{mg} \mathrm{L}^{-1}\right)\end{array}$} & \multicolumn{3}{|c|}{$\begin{array}{l}\text { Potentially plant toxic ions in } \\
\text { the irrigation water }\left(\mathrm{mg} \mathrm{L}^{-1}\right)\end{array}$} & \multicolumn{3}{|c|}{ Additional parameters } \\
\hline & $\begin{array}{l}\text { Sulphate } \\
\left(\mathrm{SO}_{4}\right)\end{array}$ & $\begin{array}{l}\text { Calcium } \\
\text { (Ca) }\end{array}$ & $\begin{array}{l}\text { Potassium } \\
\text { (K) }\end{array}$ & $\begin{array}{l}\text { Magnesium } \\
(\mathrm{Mg})\end{array}$ & $\begin{array}{l}\text { Phosphate } \\
\left(\mathrm{PO}_{4}\right)\end{array}$ & $\begin{array}{l}\text { Chloride } \\
\text { (Cl) }\end{array}$ & $\begin{array}{l}\text { Sodium } \\
(\mathrm{Na})\end{array}$ & Boron (B) & $\begin{array}{l}\text { Electrical } \\
\text { Conductivity } \\
\left(\mathrm{dS} \mathrm{m}^{-1}\right)\end{array}$ & $\mathrm{pH}$ & $\begin{array}{l}\text { Sodium } \\
\text { adsorption } \\
\text { ratio (SAR) }\end{array}$ \\
\hline $\begin{array}{l}\text { Khirbet As } \\
\text { Samra }\end{array}$ & 65.09 & 44.55 & 31.32 & 27.22 & 35.63 & 364.61 & 261.14 & 0.91 & 2.14 & 7.86 & 7.67 \\
\hline Ramtha & 104.66 & 49.71 & 32.97 & 34.19 & 6.80 & 398.76 & 232.46 & 0.73 & 1.71 & 8.21 & 6.30 \\
\hline $\begin{array}{l}\text { King Talal } \\
\text { Reservoir }\end{array}$ & 90.78 & 50.09 & 15.74 & 31.39 & 21.74 & 276.66 & 125.67 & 0.54 & 1.91 & 7.85 & 1.92 \\
\hline $\begin{array}{l}\text { Tap water } \\
\text { (Amman) }\end{array}$ & 52.90 & 56.47 & 5.36 & 20.61 & 4.13 & 153.38 & 65.41 & $<0.0016$ & 0.79 & 6.90 & 1.89 \\
\hline
\end{tabular}

\section{$173 \times 65 \mathrm{~mm}(600 \times 600 \mathrm{DPI})$}


Electrical Conductivity of the soil saturation extract ( $\left.\mathrm{dS} \mathrm{m}^{-1}\right)$

$152 \times 132 \mathrm{~mm}(600 \times 600 \mathrm{DPI})$ 